\title{
Changes in Instrumental Textural and Color Attributes of Pre-Treated Potato Slices during Refrigerated Storage
}

\author{
Bülent Ergönül* and Kıvılcım Çelik \\ Department of Food Engineering, Turkey \\ *Corresponding author: Bülent Ergönül, Department of food engineering, Turkey
}

Submission: December 13, 2018; Published: January 22, 2019

\begin{abstract}
In this research it was aimed to determine the effect of using ascorbic acid for pre-treatment on the instrumental textural attributes and color values of potato slices during refrigerated storage. Solutions of $1 \%, 2 \%$ or $3 \%(\mathrm{w} / \mathrm{v})$ ascorbic acid were used for pre-treatment of the potato slices. As results of the analysis, it was determined that hardness value of control sample significantly declined during the refrigerated storage $(\mathrm{P}<0.05)$ whereas hardness value of potato slices which were pre-treated by using $\% 2$ or $\% 3$ ascorbic acid did not change ( $P>0.05)$. Furthermore, it was observed that $L$ hunter color value of potato slices did not change with the concentration of the pre-treatment solution $(\mathrm{P}>0.05)$. On the other hand, average $a$ and $b$ values of the samples significantly decreased during refrigerated storage $(\mathrm{P}<0.05)$. Average color scores of pre-treated potato slices were significantly higher from the average color scores of control sample at the end of the storage $(\mathrm{P}<0.05)$. There was a high correlation $(\mathrm{r}=0.78)$ was determined among the $\mathrm{b}$ values and sensorial color scores of potato slices.
\end{abstract}

Keywords: Potato slices; Instrumental textural attributes; Hunter color value; Refrigerated storage

\section{Introduction}

Quality of potatoes is defined as a combination of physicochemical and nutritional attributes which are influenced by storage conditions [1]. Potatoes should be firm, smooth, having no defects and undesired colors [2]. According to Clydesdale [3], color and texture of a product are the primary concerns to consumers as indicators of food quality. Texture is widely known as the resistance of the food product to the force applied. During storage, textural attributes of potato changes due to the storage conditions like temperature, relative humidity or packaging materials if used [4]. Shelf life of cut potatoes is rather limited due to the enzymatic browning occurs on cut surface. This causes discoloration. Main reasons of this discoloration are known as polyphenol oxidase catalyzed oxidation of phenolic compounds and their condensation to dark colored pigments [5]. Many chemicals were used for the prevention of this undesired quality loss, but because of adverse health effects, usage of sulfites was banned by Food and Drug Administration many years ago. According to Raju et al. [6] and Bieganska-Marecik \& Czapski [7] ascorbic acid can be used as inhibitor against enzymatic browning and tissue softening.

\section{Materials and Methods}

Potato (Solarium tuberosum L.) tubers were purchased from a local market in Karşıyaka, İzmir. Slices of about 6-7cm diameter were cut. Ascorbic acid solutions at concentrations of 1.0\%, 2.0\% and $3.0 \%(\mathrm{w} / \mathrm{v})$ were prepared. The ratio between the solids (sliced potatoes) and the soaking solution was 1:3. During the immersion, the solution was agitated for $2 \mathrm{~min}$. After each assay, the potato slices were gently dried for $1 \mathrm{~min}$ with a manual centrifugal machine.

$100 \mathrm{~g}$ of the potato slices were packaged by using an automatic packaging machine (Henkelman Vacuum System, Netherlands). Linear low density polyethylene material 002802 permeability

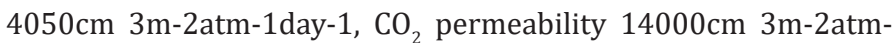
1day-1) was used for packaging for each batch of samples. Dimensions of the package material were $200 \mathrm{~mm}$ and $150 \mathrm{~mm}$, whereas the thickness of the package was $50 \mu \mathrm{m}$. Package materials were purchased from Arti Packaging, İzmir. Packaged samples were kept at $4 \pm 1{ }^{\circ} \mathrm{C}$ for 8 days and instrumental textural attributes and color values of the samples were determined on $1^{\text {st }}, 3^{\text {rd }}, 6^{\text {th }}$ and $8^{\text {th }}$ days of the storage.The color values of samples were evaluated with a colorimeter (Minolta, Osaka, Japan). L, a, and b (Hunter) parameters were measured. A white tile (L 93.3, a 0.3162, b 0.3321) was used as reference for the calibration. Ten measures were performed for each sample under each condition and then average values and standard deviations were determined [8].

Instrumental textural measurements were made using a computer-controlled TA-XT Texture Analyzer (Vienna Court, Surrey Gu7 YL, England). Thickness of the samples was $10 \mathrm{~mm}$. 
For determination of hardness and toughness of the samples, Warner-Bratzler blade was used $[9,10]$. Test speed was $1 \mathrm{~mm} / \mathrm{sn}$. The peak point of the curve obtained was determined as Firmness $(\mathrm{N})$, whereas the area under the peak was calculated and named as Toughness (N.s). Load was $50 \mathrm{~kg}$. Sensorial color evaluation of potato slices were performed by 7 trained faculty staff. 5 pointscale was used for evaluation of color. Score 1 was used for the unacceptable color (dislike extremely), whereas 5 was indicating the desired (like extremely) yellow potato color [11]. Findings obtained from the analyses were evaluated by the GLM procedure of the SAS Statistical Analyses Programmed according to the completely randomized design [12]. Duncan analysis was applied on the results found statistically significant $(\mathrm{P}<0.05)$ [13]. All analyses were performed in duplicate.

\section{Results and Discussion}

Changes in instrumental textural attributes of pre-treated potato samples were given as Table 1 . As seen from the table, on the beginning day of the research average hardness values of the samples for $152.99 \mathrm{~N}, 130.83 \mathrm{~N}, 129.96 \mathrm{~N}$ and $137.90 \mathrm{~N}$ respectively for CNT, $1 \%-\mathrm{AA}, 2 \%-\mathrm{AA}$ and 3\%-AA. On the third day of the refrigerated storage, hardness value of CNT decreased to $142.83 \mathrm{~N}$ but this decrease was not found statistically significant $(\mathrm{P}>0.05)$. Average hardness values of all samples did not show any significant changes during the first 3 days of the refrigerated storage $(\mathrm{P}>0.05)$. But on the $6^{\text {th }}$ day and the $8^{\text {th }}$ day of the refrigerated storage, average hardness value of control sample significantly decreased $(\mathrm{P}<0.05)$. At the end of the refrigerated storage, average hardness value of control sample was $117.99 \mathrm{~N}$. Similar data was obtained for the sample 1\%-AA which was pre-treated by using $\% 1(\mathrm{w} / \mathrm{v})$ ascorbic acid. At the beginning of the study average hardness value of this samples was $130.83 \mathrm{~N}$, whereas at the end of the storage period, average hardness value significantly declined and became 102.72N $(\mathrm{P}<0.05)$. On the other hand, as it can be seen from Table 1 , average hardness values of the samples which were pre-treated by using $2 \%$ or $3 \%$ ascorbic acid solution did not show any statistically significant changes during refrigerated storage $(\mathrm{P}>0.05)$. Also, toughness value of the sample $3 \%$-AA did not change during storage at $4{ }^{\circ} \mathrm{C}(\mathrm{P}>0.05)$, whereas average toughness values of CNT, $1 \%$-AA or $2 \%$-AA significantly decreased during refrigerated storage $(\mathrm{P}<0.05)$.

Table 1: Changes in instrumental textural attributes of potato samples during refrigerated storage.

\begin{tabular}{|c|c|c|c|c|c|c|c|c|}
\hline \multirow[b]{2}{*}{ Sample } & \multicolumn{2}{|c|}{ Day-1 } & \multicolumn{2}{|c|}{ Day-3 } & \multicolumn{2}{|c|}{ Day-6 } & \multicolumn{2}{|c|}{ Day-8 } \\
\hline & Hardness(N) & Toughness(N.s) & Hardnesss(N) & Toughness (N.s) & $\begin{array}{c}\text { Hardness } \\
\text { (N) }\end{array}$ & $\begin{array}{c}\text { Toughness } \\
\text { (N.s) }\end{array}$ & Hardness(N) & Toughness(N.s) \\
\hline CNT & $152.99^{\mathrm{A}}$ & $335.04^{\mathrm{A}}$ & $142.83^{\mathrm{A}}$ & $263.52^{\mathrm{B}}$ & $116.46^{\mathrm{B}}$ & $178.56^{\mathrm{C}}$ & $117.99^{\text {Bab }}$ & $170.62^{\mathrm{C}}$ \\
\hline $1 \%-\mathrm{AA}$ & $130.83^{\mathrm{A}}$ & $364.92^{\mathrm{A}}$ & $140.21^{\mathrm{A}}$ & $259.70^{\text {В }}$ & $120.34^{\mathrm{AB}}$ & $187.16^{\mathrm{BC}}$ & $102.72^{\mathrm{Bb}}$ & $165.29^{\mathrm{C}}$ \\
\hline $2 \%-\mathrm{AA}$ & 129.96 & $337.87^{\mathrm{A}}$ & 108.35 & $175.26^{\mathrm{B}}$ & 111.64 & $171.63^{\mathrm{B}}$ & $112.78^{\mathrm{ab}}$ & $174.27^{\mathrm{B}}$ \\
\hline 3\%-AA & 137.9 & 288 & 103.81 & 185.43 & 110.94 & 184.18 & $138.79^{a}$ & 186.02 \\
\hline
\end{tabular}

Values with different capital letters in a row are significantly different from each other $(\mathrm{P}<0.05)$

Values with different small letters in a column are significantly different from each other $(\mathrm{P}<0.05)$

Table 2: Changes in hunter 1 values of potato samples during refrigerated storage.

\begin{tabular}{|c|c|c|c|c|}
\hline Sample & $\mathbf{1}^{\text {st }} \mathbf{d a y}$ & $\mathbf{3}^{\text {rd }} \mathbf{d a y}$ & $\mathbf{6}^{\text {th }}$ day & $\mathbf{8}^{\text {th }}$ day \\
\hline CNT & $75.76^{\mathrm{A}}$ & $73.62^{\mathrm{ABb}}$ & $71.71^{\mathrm{B}}$ & $74.21^{\mathrm{A}}$ \\
\hline $1 \%-\mathrm{AA}$ & $77.11^{\mathrm{A}}$ & $73.1^{\mathrm{Bb}}$ & $72.26^{\mathrm{B}}$ & $72.94^{\mathrm{B}}$ \\
\hline $2 \%-A A$ & $76.62^{\mathrm{A}}$ & $76.21^{\mathrm{Aa}}$ & $72.96^{\mathrm{B}}$ & $73.58^{\mathrm{B}}$ \\
\hline $3 \%-A A$ & $77.25^{\mathrm{A}}$ & $75.22^{\mathrm{Ba}}$ & $72.43^{\mathrm{C}}$ & $72.82^{\mathrm{C}}$ \\
\hline
\end{tabular}

Values with different capital letters in a row are significantly different from each other $(\mathrm{P}<0.05)$

Values with different small letters in a column are significantly different from each other $(\mathrm{P}<0.05)$

Table 1 changes in instrumental textural attributes of potato samples during refrigerated storage changes in Hunter $L, a$, b values of potato samples during refrigerated storage were given as Table 2-4. As seen from Table 2, on the first day of the research, average Hunter L values of potato samples were among 75.76 and 77.25.
On the $3^{\text {rd }}$ day of the refrigerated storage, it was seen that average $\mathrm{L}$ values of the samples decreased significantly $(\mathrm{P}<0.05)$. Similar data was obtained on the $6^{\text {th }}$ day of refrigerated storage and average $\mathrm{L}$ values of potato samples significantly decreased to levels changing among 71.71 and $72.96(\mathrm{P}<0.05)$. On the other hand, on the $8^{\text {th }}$ and the last day of the storage, average $L$ values of the samples $1 \%$ $\mathrm{AA}, 2 \%-\mathrm{AA}$ and 3\%-AA increased but this increase was not found significantly important $(\mathrm{P}>0.05)$.

Changes in Hunter a values of potato samples were given as Table 4. As seen from the table on the first day refrigerated storage, average a value of control sample was 3.16, whereas average a values of $1 \%$-AA, $2 \%$-AA and $3 \%$-AA were $4.07,4.03$, and 4.00 respectively and there was no significant difference was observed among the a values of the samples $(\mathrm{P}>0.05)$. On the $3^{\text {rd }}$ day of the storage, a value of the samples decreased significantly to levels changing among 2.27 and 3.69 except the sample $2 \%$-AA but the increase in a value of sample 2\%-AA was not found significantly important $(\mathrm{P}>0.05)$. On the sixth day of the storage only a value 
of the sample $2 \%-\mathrm{AA}$ increased $(\mathrm{P}<0.05)$ but a value of the other samples remained already the same $(\mathrm{P}>0.05)$. The most significant change in average a value of the samples was observed on the last day of the refrigerated storage. On that period, average a value of the samples were among -1.78 and -2.93 .

Table 3: Changes in hunter a values of potato samples during refrigerated storage.

\begin{tabular}{|l|l|l|l|l|}
\hline Sample & $\mathbf{1}^{\text {st }} \mathbf{d a y}$ & $\mathbf{3}^{\text {rd }} \mathbf{d a y}$ & $\mathbf{6}^{\text {th }} \mathbf{d a y}$ & $\mathbf{8}^{\text {th }} \mathbf{d a y}$ \\
\hline $\mathrm{CNT}$ & $3.16^{\mathrm{A}}$ & $2.69^{\mathrm{Ac}}$ & $2.37^{\mathrm{A}}$ & $-2.93^{\mathrm{B}}$ \\
\hline $1 \%-\mathrm{AA}$ & $4.07^{\mathrm{A}}$ & $2.27^{\mathrm{Abc}}$ & $2.69^{\mathrm{A}}$ & $-2.63^{\mathrm{B}}$ \\
\hline $2 \%-\mathrm{AA}$ & $4.03^{\mathrm{A}}$ & $4.17^{\mathrm{Aa}}$ & $2.62^{\mathrm{B}}$ & $-2.71^{\mathrm{C}}$ \\
\hline $3 \%-\mathrm{AA}$ & $4.00^{\mathrm{A}}$ & $3.69^{\mathrm{Aab}}$ & $2.52^{\mathrm{A}}$ & $-1.78^{\mathrm{B}}$ \\
\hline
\end{tabular}

Values with different capital letters in a row are significantly different from each other $(\mathrm{P}<0.05)$

Values with different small letters in a column are significantly different from each other $(\mathrm{P}<0.05)$

Table 4: Changes in hunter $b$ values of potato samples during refrigerated storage.

\begin{tabular}{|c|c|c|c|c|}
\hline Sample & $\mathbf{1}^{\text {st }}$ day & $\mathbf{3}^{\text {rd }}$ day & $\mathbf{6}^{\text {th }}$ day & $\mathbf{8}^{\text {th }}$ day \\
\hline CNT & 38.96 & $38.82^{\mathrm{b}}$ & 35.28 & 29.1 \\
\hline $1 \%-A A$ & $42.94^{\mathrm{A}}$ & $38.23^{\mathrm{Bab}}$ & $38.86^{\mathrm{B}}$ & $36.18^{\mathrm{B}}$ \\
\hline $2 \%-A A$ & $41.54^{\mathrm{A}}$ & $42.06^{\mathrm{Aa}}$ & $38.09^{\mathrm{B}}$ & $36.83^{\mathrm{B}}$ \\
\hline $3 \%-A A$ & $42.70^{\mathrm{A}}$ & $41.90^{\mathrm{ABab}}$ & $37.23^{\mathrm{B}}$ & $35.86^{\mathrm{B}}$ \\
\hline
\end{tabular}

Values with different capital letters in a row are significantly different from each other $(\mathrm{P}<0.05)$

Values with different small letters in a column are significantly different from each other $(\mathrm{P}<0.05)$

Hunter $\mathrm{b}$ values of potato samples were given as Table 4. As seen from table on the first day of refrigerated storage, average $b$ values of the samples CNT, $1 \%$-AA, $2 \%$-AA and $3 \%$-AA were 38.96 , $42.94,41.54$ and 42.70 and there were no significant differences observed among them $(\mathrm{P}>0.05)$. During 8-day refrigerated storage average $b$ value of control sample did not change $(\mathrm{P}>0.05)$ whereas average $b$ values of other pre-treated samples significantly decreased during storage $(\mathrm{P}<0.05)$. As seen from on the first day of the storage, average color score of the samples was 4.57. Average color score of control samples significantly declined to 2.29 at the end of the refrigerated storage $(\mathrm{P}<0.05)$. Average color scores of pre-treated potato slices were significantly higher from the average color scores of control sample at the end of the storage $(\mathrm{P}<0.05)$. There was a high correlation ( $\mathrm{r}=0.78$ ) was determined among the $\mathrm{b}$ values and sensorial color scores of potato slices.

\section{Conclusion}

As a conclusion, using ascorbic acid as a pre-treatment agent had a positive effect on instrumental textural attributes of potato slices. According to data obtained hardness values of the samples 2\%-AA and 3\%-AA which were pre-treated by using ascorbic acid solution, did not change significantly during refrigerated storage $(\mathrm{P}>0.05)$. On the other hand, hardness value of untreated (control) sample significantly decreased during refrigerated storage. It is thought that hardness of a potato sample is of great importance in terms of consumer acceptance and food quality especially when kept at refrigerated conditions. Also average toughness of the sample 3\%-AA did not change significantly during the 8-day refrigerated storage $(\mathrm{P}>0.05)$.

\section{References}

1. Nourian F, Ramaswamy HS, Kushalappa AC (2003) Kinetics of quality change associated with potatoes stored at different temperatures. Lebensmittel Wissenchaft Technologie (LWT) 36: 49-65.

2. Pardo JE, Alvarruiz A, Perez JI, Gomez R, Varon R (2000) Physicalchemical and sensory quality evaluation of potato varieties (Solanım tuberosum L). Journal of Food Quality 23(2): 149-160.

3. Clydesdale FM (1991) Color perception and food quality. Journal of Food Quality 14: 61-74.

4. Alvarez MD, Canet W (2000) Storage time effect on the rheology of refrigerated potato tissue (cv. Monalisa). European Food Research and Technology 212(1): 48-56.

5. Sapers GM, Miller RL (1992) Enzymatic browning control in potato with ascorbic acid 2-phosphates. Journal of Food Science 57(5): 1132-1135.

6. Raju PS, Ashok N, Das Gupta DK (2000) Physiological and quality changes during minimal processing and storage of shredded cabbage. Indian Food Packer, pp. 51-55.

7. Bieganska MR, Czapski J (2007) The effect of selected compounds as inhibitors of enzymatic browning and softening of minimally processed apples. Acta Scientiarum Polonorum Technol. Aliment 6(3): 37-49.

8. Gönül M, Altuğ T, Boyacıoğlu D, Noka U Gıda Analizleri (1988) Ege university engineering faculty publications, Bornova, İzmir, Turkey, p. 64.

9. Lin MT, Durance TD, Scaman CH (1998) Characterization of vacuum microwave, air- and freeze-dried carrot slices. Food Research International 31(2):111-117.

10. Rastogi NK, Nguyen LT, Balasubramaniam V (2000) Effect of pretreatments on carrot texture after thermal and pressure-assisted thermal processing. Journal of Food Engineering 88: 541-547.

11. Lawless HT, Heymann H (1999) Sensory evaluation of food: Principles and Practices. Springer, Boston, Massachusetts, USA.

12. SAS (2001) Statistical analysis programme. University of Purdue, Lafayette, Indiana, USA.

13. Sante V, Fernandez X (2000) The measurement of pH in raw and frozen turkey pectopralis supercialis muscle. Meat Sci 55(4): 503-506. 
(c) (i) Creative Commons Attribution 4.0 International License

For possible submissions Click Here

Submit Article NTNF

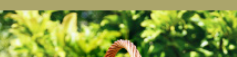
3.) and

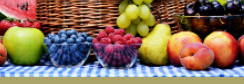

Novel Techniques in Nutrition and Food Science

\section{Benefits of Publishing with us}

- High-level peer review and editorial services

- Freely accessible online immediately upon publication

- Authors retain the copyright to their work

- Licensing it under a Creative Commons license

- Visibility through different online platforms 